\section{Pecan Cultivars Differ Greatly in Susceptibility to June Drop}

\author{
Ray E. Worley ${ }^{1}$ \\ Department of Horticulture, University of Georgia, Coastal Plain Experiment \\ Station, Tifton, GA 31793-0748
}

Additional index words. abscission, abortion, nut drop, nut set, Carya illinoinessis

In Spring 1993, 'Oconee' pecan [Carya illinoinessis (Wangenh.) K. Koch] (Thompson et al., 1991) had a heavy pistillate bloom, indicating a usual good crop; however, the June drop, frequently attributed to poor pollination (Smith, 1982; Sparks and Madden, 1985), appeared unusually severe, resulting in only $18 \mathrm{~kg}$ nuts per tree. This low yield seemed to be an excessive drop problem that did not affect other cultivars in 1993. A similar heavy pistillate bloom and subsequent drop of 'Oconee' in 1994 stimulated this study to determine if 'Oconee' had a higher June drop than other cultivars.

Sixteen cultivars were planted in a randomized complete-block design with four replications and single-tree plots in Spring 1979. Later, 29 additional cultivars were planted upwind from the 16 cultivars. Trees in both parts of the planting shed pollen when 'Oconee' was receptive; therefore, opportunity for pollination was optimum (Worley et al., 1992). Trees were spaced $12.2 \times 12.2 \mathrm{~m}$ and were not crowded. Four routine Super-Tin fungicide (Griffin Corp., Valdosta, Ga.) sprays, but no insecticide, were applied by 9 June. A subthreshold infestation of spittlebug appeared uniformly across all cultivars.

Beginning 9 June, the number of nuts and scars where nuts had dropped were counted on 100 nut clusters per tree for the 11 cultivars that bore pistillate flowers in 1994 . The scar count omitted the small raceme scar at the

Received for publication 19 Dec. 1994. Accepted for publication 11 Mar. 1995. This research was supported by state and Hatch Act funds allocated to the Georgia Agricultural Expt. Stations. The cost of publishing this paper was defrayed in part by the payment of page charges. Under postal regulations, this paper therefore must be hereby marked advertisement solely to indicate this fact.

${ }^{1}$ Professor.

Table 1. Yield and nut drop of 16 pecan cultivars. apex of the flower cluster (Yates and Sparks, 1994). 'Caddo', 'Gloria Grande', and 'Owens' cropped consistently in both years (Table 1). Most cultivars set about the same number of nuts initially (nuts + scars) (Table 1). 'Forkert' started with fewer nuts per cluster and 'Caddo' and 'Shawnee' started with more nuts per cluster than the others in 1994. After the June drop, 'Shawnee' kept more nuts per cluster than 'Caddo'. The high nut set for 'Shawnee' in 1994 may be related to the light crop in 1993. Total nut set (nuts + scars) was significantly and negatively correlated with yield in $1993(r=-0.42, P \leq 0.01)$, but yield in the off year of 1994 was not related to total nut set (nuts + scars) the same year.

'Oconee' started with an intermediate nut set but dropped the highest percentage of nuts and left the fewest nuts per cluster of the cultivars surveyed (Table 1). 'Oconee' averaged only 1.2 nuts per cluster in June, but its yield (34 kg/tree) was in the highest yield category (Table 1). Obviously, a high nutsper-cluster count in June is not necessary for good yield, and other cultivars dropped more nuts before harvest. In 1994, yield was corre-

lated negatively with nuts per cluster in June ( $r$ $=-0.43 ; P \leq 0.01)$ and positively with the number $(r=0.54)$ and percentage of nuts dropped $(r=0.56)$ in the June drop. A June drop that would leave about one to two nuts per cluster seems desirable to have a good crop of nuts.

'Shawnee' set more nuts per cluster than any other cultivar and dropped few of them (Table 1), causing overload and poor fill (data not shown). 'Owens' ranked second in percentage of nuts dropped but had excellent yield and better than usual kernel quality.

A moderate June drop in pecan might be desirable in some years to prevent overloading and stress that may create shuck decline problems (Sparks et al., 1994). The extent and implications of the June drop for 'Oconee' at other locations remains to be investigated.

\section{Literature Cited}

Smith, M.W. 1982. Factors associated with nut abortion in pecan. HortScience 17:147-148.

Sparks, D. and G.D. Madden. 1985. Pistillate flower and fruit abortion in pecan as a function of cultivar, time and pollination. J. Amer. Soc. Hort. Sci. 110:219-223.

Sparks, D., W. Reed, I.E. Yates, M.W. Smith, and T.G. Stevenson. 1994. Fruiting stress induces shuck decline and premature germination in pecan. J. Amer. Soc. Hort. Sci. 120:43-53.

Thompson, T.E., E.F. Young, H.D. Peterson, L.J. Grauke, R.E. Worley, R.D. O'Barr, and R.S. Sanderlin. 1991. 'Oconee' pecan. HortScience 26:1099-1100.

Worley, R.E., S.K. Dove, B.G. Mullinix, and M. Smith. 1992. Long-term dichogamy of 80 pecan cultivars. Scientia Hort. 49:93-101.

Yates, I.E. and D. Sparks. 1994. Pistillate flower abortion. Proc. Southeastern Pecan Growers Assn. 87:184-194.

\begin{tabular}{|c|c|c|c|c|c|c|}
\hline \multirow[b]{2}{*}{ Cultivar } & \multicolumn{2}{|c|}{$\begin{array}{c}\text { Yield } \\
\text { (kg/tree) }\end{array}$} & \multirow{2}{*}{$\begin{array}{l}\text { Nuts/ } \\
\text { cluster }\end{array}$} & \multirow{2}{*}{$\begin{array}{l}\text { Scars/ } \\
\text { cluster }\end{array}$} & \multirow{2}{*}{$\begin{array}{c}\text { Total } \\
\text { (nuts }+ \\
\text { scars) }\end{array}$} & \multirow{2}{*}{$\begin{array}{l}\text { Percent } \\
\text { dropped }\end{array}$} \\
\hline & 1993 & 1994 & & & & \\
\hline$\overline{\text { Caddo }}$ & $36 \mathrm{~b}-\mathrm{e}$ & $29 \mathrm{ef}$ & $2.95 \mathrm{f}$ & $1.08 \mathrm{e}$ & $4.03 \mathrm{c}$ & $28 \mathrm{~d}-\mathrm{f}$ \\
\hline Cape Fear & $49 \mathrm{de}$ & $10 \mathrm{~b}-\mathrm{d}$ & $2.82 \mathrm{ef}$ & $0.27 \mathrm{a}$ & $3.10 \mathrm{~b}$ & $9 \mathrm{a}$ \\
\hline Cheyenne & $44 \mathrm{~b}-\mathrm{e}$ & $7 \mathrm{a}-\mathrm{c}$ & $2.71 \mathrm{~d}-\mathrm{f}$ & $0.51 \mathrm{ab}$ & $3.22 \mathrm{~b}$ & $16 \mathrm{a}-\mathrm{c}$ \\
\hline Forkert & $45 \mathrm{c}-\mathrm{e}$ & $14 \mathrm{~cd}$ & $1.74 \mathrm{~b}$ & $0.69 \mathrm{~b}-\mathrm{d}$ & $2.43 \mathrm{a}$ & $28 \mathrm{~d}-\mathrm{f}$ \\
\hline Gloria Grande & $48 \mathrm{de}$ & $36 \mathrm{f}$ & $1.98 \mathrm{bc}$ & $1.04 \mathrm{de}$ & $3.02 \mathrm{~b}$ & $34 \mathrm{f}$ \\
\hline Linberger & $55 \mathrm{ef}$ & $18 \mathrm{~d}$ & $2.32 \mathrm{~cd}$ & $0.70 \mathrm{~b}-\mathrm{d}$ & $3.02 \mathrm{~b}$ & $23 c-e$ \\
\hline Oconee & $18 \mathrm{a}$ & $34 \mathrm{f}$ & $1.17 \mathrm{a}$ & $2.19 \mathrm{~g}$ & $3.36 \mathrm{~b}$ & $65 \mathrm{~h}$ \\
\hline Osage & $27 a b$ & $18 \mathrm{~d}$ & $2.37 \mathrm{c}-\mathrm{e}$ & $0.99 \mathrm{c}-\mathrm{e}$ & $3.36 \mathrm{~b}$ & 29 ef \\
\hline Owens & $46 \mathrm{c}-\mathrm{e}$ & $28 \mathrm{ef}$ & $1.56 \mathrm{ab}$ & $1.50 \mathrm{f}$ & $3.06 \mathrm{~b}$ & $48 \mathrm{~g}$ \\
\hline Shawnee & $11 \mathrm{a}$ & $18 \mathrm{~d}$ & $3.56 \mathrm{~g}$ & $0.54 \mathrm{ab}$ & $4.10 \mathrm{c}$ & $13 \mathrm{ab}$ \\
\hline $40-9-266$ & $45 \mathrm{c}-\mathrm{e}$ & $3 a b$ & $2.70 \mathrm{~d}-\mathrm{f}$ & $0.66 \mathrm{bc}$ & $3.36 \mathrm{~b}$ & $20 b-d$ \\
\hline
\end{tabular}

${ }^{\mathrm{z}}$ Mean separation in columns by GLM TDiff option at $P \leq 0.05$. 